\title{
A brief radiological survey and associated occupational exposure to radiation in an open pit slate mine in Kashan, Iran
}

\author{
Amin Shahrokhi ${ }^{1}$ (D) Mohammademad Adelikhah ${ }^{1} \cdot$ Morteza Imani $^{2} \cdot$ Tibor Kovács $^{1}$
}

Received: 18 January 2021 / Accepted: 8 May 2021 / Published online: 2 June 2021

(c) The Author(s) 2021

\begin{abstract}
A comprehensive radiological survey was carried out in an open-cut slate stone quarry. The activity of ${ }^{226} \mathrm{Ra},{ }^{228} \mathrm{Ra}$ and ${ }^{40} \mathrm{~K}$ in the ore samples were measured as $38 \pm 5,41 \pm 6$ and $869 \pm 52 \mathrm{~Bq} \mathrm{~kg}^{1}$, respectively. Outdoor radon and indoor radon concentrations were measured from $37 \pm 7$ to $193 \pm 11 \mathrm{~Bq} \mathrm{~m}^{-3}\left(77 \pm 8 \mathrm{~Bq} \mathrm{~m}^{-3}\right)$, and $49 \pm 6$ to $253 \pm 23 \mathrm{~Bq} \mathrm{~m}^{-3}\left(131 \pm 13 \mathrm{~Bq}^{-3}\right.$ $\mathrm{m}^{-3}$ ), respectively. The average indoor and outdoor gamma dose were measured as 116 and $84 \mathrm{nSv} \mathrm{h}^{-1}$, respectively. The annual effective doses were estimated between $1.0 \pm 0.1$ and $3.3 \pm 0.3 \mathrm{mSv}_{\mathrm{year}}{ }^{-1}$. The annual lung cancer risks were calculated in the range of $3.3 \times 10^{-2}$ to $13.12 \times 10^{-2} \%\left(7.72 \times 10^{-2} \%\right)$.
\end{abstract}

Keywords Health risk assessment $\cdot$ Radiation dose $\cdot$ Occupational exposure $\cdot$ Environmental radioactivity $\cdot$ Cancer risk

\section{Introduction}

In recent years, the potential health risk of radiation has been a concern by national and international health organizations, so that it requires them to set recommendations and regularly update them both for workers and the general population. Radon is a carcinogenic gas, in consideration of its short half-life decay products, has been recognized as the second reason for lung cancer among people after smoking, while it is the main path of exposure to ionization radiation among other naturally occurring sources $[1,2] .{ }^{222} \mathrm{Rn}\left(\mathrm{T}_{1 / 2}=3.8\right.$ days) is a progeny of ${ }^{226} \mathrm{Ra}$ in the ${ }^{238} \mathrm{U}$ chain. Uranium-238 can be found in the Earth crust, rock, and stones, which would be a radiation risk for miners. Once radon escaped from grains and entered the pores, it moves by diffusion to reach the material's surface and then exhaled from the surface through the cracks, faults, and rock fractures. According to IAEA, the annual average radon concentration at workplaces shall not exceed $1000 \mathrm{~Bq} \mathrm{~m}^{-3}$. Likewise, the received dose from radon and its short-life decay products should not be above the value of $20 \mathrm{mSv}$ per year for each worker

Amin Shahrokhi

ashahrokhi@almos.uni-pannon.hu

1 Department of Radiochemistry and Radioecology, University of Pannonia, Veszprem, Hungary

2 Engineering Department, Shahid Beheshti University, Tehran, Iran
[3]. ICRP and WHO established a recommended value for indoor radon concentration as $300 \mathrm{~Bq} \mathrm{~m}^{-3}$ and a limit of 20 $\mathrm{mSv}$ year ${ }^{-1}$ for received dose in workplaces [2, 4].

Radon is one of the main pathways of occupational exposure to ionization radiation in underground and uranium mines [5]. Accumulated radon concentration in the mine depends on the mine conditions, e.g., ventilation, temperature, humidity, pressure, apart from the geological formations of the mine. However, the operating environment of open-cut mines is relatively more reliable compared to underground mines, it contains several hazards within itself, such as naturally radioactive materials releasing in the form of dust, hazardous gases such as radioactive radon gas, etc. Therefore, radon distribution and its origin in mines are essential according to radiation-protection standards.

Slate stones, known as fine-grained sedimentary rock, have some uranium and radium, which eventually decay to radon and release into ambient air following the diffusion and exhalation process. The increased interest in monitoring radon concentration slate mines is due to the health hazards of radon and its environmental pollutant, leading to the minimization of such radiation exposure in the mine area.

In this study, the authors initially tried to: (1) determine the activity of the main natural radionuclides $\left({ }^{40} \mathrm{~K},{ }^{226} \mathrm{Ra}\right.$ and ${ }^{228} \mathrm{Ra}$ ) in ore samples; (2) measure the external gamma dose and radon exposure to assess the radiation risk. As a result of these measurements, the occupational annual effective dose was estimated to compare with the worldwide 
average value. Likewise, the cancer risk was calculated individually for each worker using personal dosimeters.

\section{Methods and measurements}

\section{Study area}

In this short communication, an open-pit slate stone mine located in Kashan, including three separate sites with an area of approximately fourteen hectares, was selected to measure the radon concentration as a significant contributor to the health hazard. The experiment had consisted of fifteen workers-including miners, drivers, engineers, and clerks-who were randomly selected from a total of 35 employees as a representative group to estimate the occupational exposure to the natural radiation sources. Radon concentration in the mine atmosphere was measured at four locations (Fig. 1) in each site for 30 days.

\section{Instrumentations and measurement techniques}

A portable radon monitor device, AlphaGUARD PQ 2000 PRO (ionizing chamber), was used to measure the radon concentration. The AlphaGUARD was set up for a 60 -min diffusion mode, and at the end of each $24 \mathrm{~h}$, data was extracted by DataExport software [6]. This measurement was carried out to estimate radon concentration in the mine area as a control value. This value could be used as a tool to identify and distinguish the suspicious results from personal dosimetry in such a way that if any result were suspiciously higher or lower than the control value, it could be eliminated from evaluation.

The surface radon exhalation from mine walls was measured using the radon accumulation chamber method (can technique) equipped with a solid nuclear track detector (CR-39). However, this part of the study was carried out as a routine process in radiological surveys, the results could give an overview relation between the activity of ${ }^{226} \mathrm{Ra}$ in ore and radon exhalation. A metallic can $(11 \mathrm{~cm}$ depth with a $6 \mathrm{~cm}$ diameter, covering a surface area of about $95 \mathrm{~cm}^{2}$ ) was used for this measurement (Fig. 2). The measurement was carried out at each site in two different locations. The minimum detection limit of the method is generally around $0.05 \mathrm{mBq} \mathrm{m}^{-2} \mathrm{~s}^{-1}$ depends on each detector background. As Eq. (1) expresses the correlation between the exhaled radon from surface and radon growth in the can $[7,8]$ :

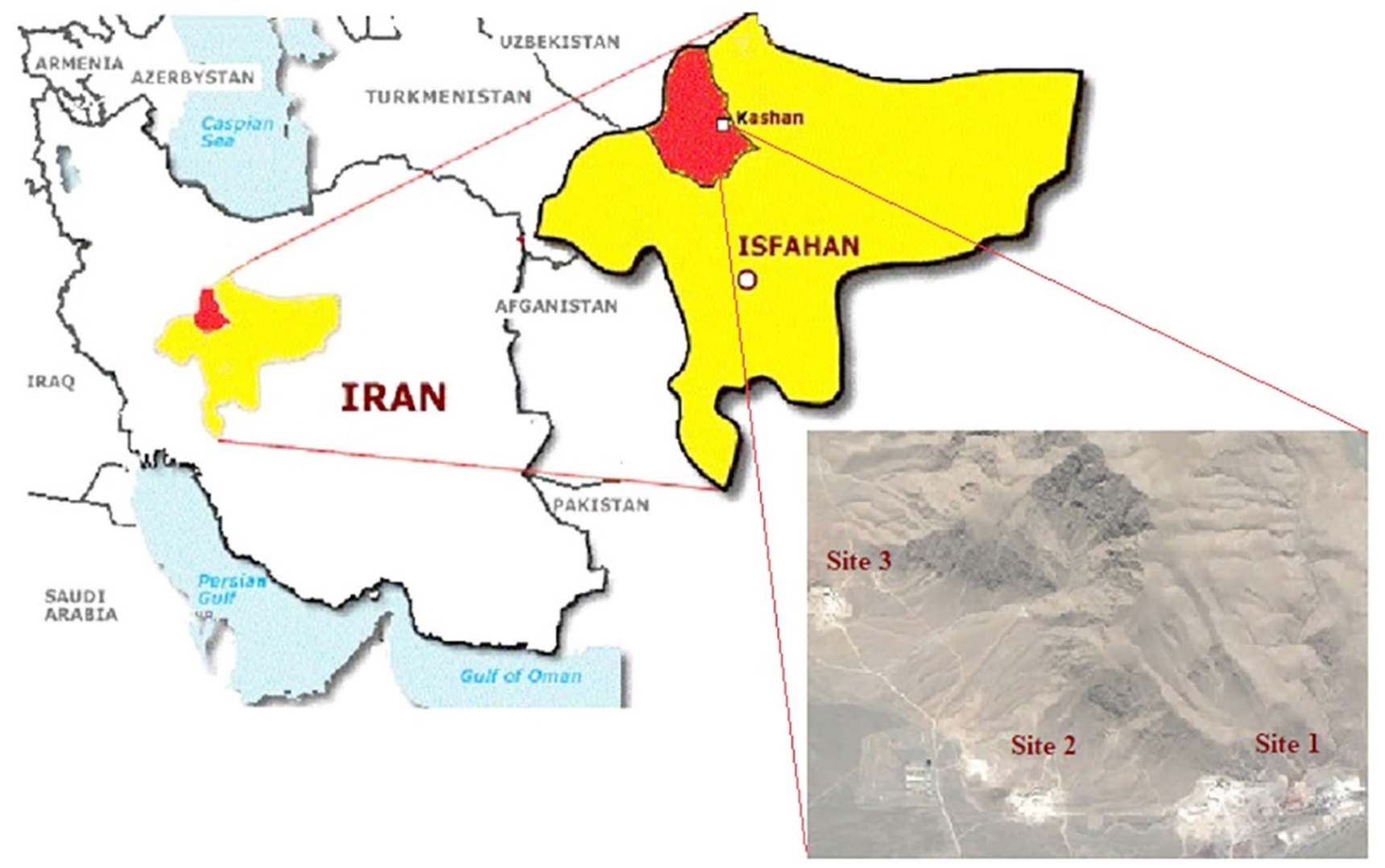

Fig. 1 Measurement sites of slate stone mine 
Fig. 2 Graphic image of radon exhalation measurement

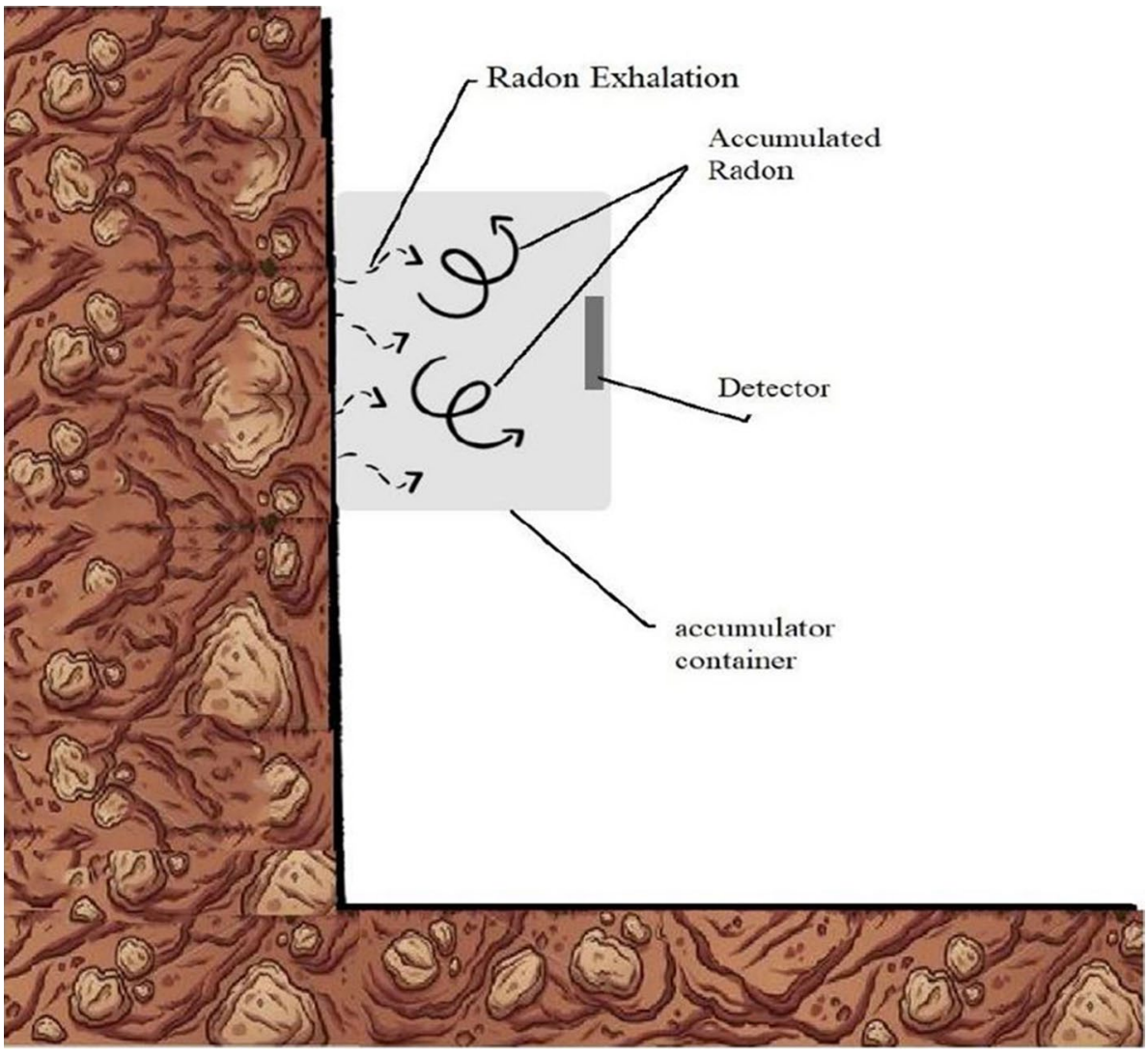

$C_{R n}=\left(\frac{E_{R n} S}{V\left(\lambda+L_{R n}\right)}\right)\left(1-e^{-\lambda \mathrm{t}}\right)$

where $C_{R n}$ is the concentration of trapped radon in the can $\left.(\mathrm{Bq} \mathrm{m})^{-3}\right), S$ as the surface area covers by the can $\left(\mathrm{m}^{2}\right), L_{R n}$ is the radon leak fraction during the accumulation time $t, V$ is the volume of the can $\left(\mathrm{m}^{3}\right)$. And the surface radon exhalation rate $\left(\mathrm{E}_{\mathrm{Rn}}\right)$ was estimated using Eq. 2 and the accumulated radon concentration from Eq. (1):

$E_{R n}=\frac{C_{R n}\left(\frac{V}{S}\right)}{1-e^{-\lambda \mathrm{t}}}$

A sodium iodide-based detector equipped by GeigerMuller tube (GR130, Exploranium Co. Ltd, Canada) was used to measure terrestrial and cosmic gamma radiation to estimate the total gamma absorbed dose rate.

An HPGe gamma-ray detector (ORTEC GMX40-76), with a relative efficiency of about 0.4 , and energy resolution between $2 \mathrm{keV}$ and $1332 \mathrm{keV}$, was used to measure the mass activity concentrations of three main naturally occurring radionuclides $\left({ }^{226} \mathrm{Ra},{ }^{228} \mathrm{Ra}\right.$ and $\left.{ }^{40} \mathrm{~K}\right)$ in the samples. The energy calibration was carried out by three closed sources of ${ }^{137} \mathrm{Cs},{ }^{60} \mathrm{Co}$ and ${ }^{241} \mathrm{Am}[9,10]$. This measurement was conducted regarding the radiological survey that might help to get a sight of the difference in the ingredients of the rocks when there is a high variation of ${ }^{226} \mathrm{Ra}$ between the samples and it can give a brief perspective of terrestrial gamma radiation contribution.

A mass of $500 \mathrm{~g}$ of each sample was separately crushed and pulverized to be less than $3 \mathrm{~mm}$. Samples were heated at $105{ }^{\circ} \mathrm{C}$ for $24 \mathrm{~h}$ to remove all moisture and reach a constant weight. Each sample was sealed into a Marinelli beaker for approximately 30 days to reach the equilibrium condition between ${ }^{226} \mathrm{Ra}$ and ${ }^{222} \mathrm{Rn}$ and its decay products. The activity of each radionuclide was determined using its specific gamma lines or gamma lines of its decay products recommended by IAEA. For further information, refer to the following references [11, 12].

To estimate the annual effective dose due to the inhalation of radon, a representative group of workers was randomly selected for radon dosimetry [13, 14]. Each worker was requested to carry on a personal CR-39 radon dosimeter during working time. It was assuring that the detectors were sealed into a radon proof zip-lock aluminium foil bag after finishing the job until the next working day. Each dosimeter had consisted of a radon gas selective chamber $(40 \mathrm{~mm}$ diameter and $32 \mathrm{~mm}$ height) and a CR-39 detector in the middle $\left(1 \mathrm{~cm}^{2}\right)$. The detectors were sent back to the laboratory for evaluation after 60 days. The evaluation process, 
including the etching and counting of the tracks, has been intensely discussed in our previous publications [15-17]. The average concentration of radon exposure was calculated from counted tracks and Eq. (3):

$E_{R n}=\left(N_{T}-N_{R}\right) \cdot E /(T \cdot \mathrm{A})$

where $E_{R n}$ is the radon exposure $\left(\mathrm{Bq} \mathrm{m}^{-3}\right), N_{T}$ is the counted tracks number, $N_{B}$ is the detector background obtained from blank detectors (control detectors), $T$ stands for exposure time in hours, $A$ is the reading area $\left(\mathrm{mm}^{2}\right)$, and $E$ is conversion factor $\left(\mathrm{Bq} \mathrm{m}^{-3} \mathrm{~h} \mathrm{~mm}^{-2}\right)$ that can be calculated by Eq. (4):

$E=R e f_{R n} \cdot T \cdot(1.025) / N$

where $E$ is the calibration factor, $R e f_{R n}$ is the reference radon concentration in the calibration chamber, $N$ is net tracks and 1.025 is the reading area $\left(\mathrm{mm}^{2}\right)$.

\section{Radiation dose calculations}

The annual exposure to radon and its progenies was calculated from Eq. (5) [1]:

$W L M_{(Y)}=C_{R n} \cdot\left(2.7 \cdot 10^{-4}\right) \cdot F \cdot \frac{h}{170} \cdot S$

where $W L M_{(Y)}$ is the cumulative radon exposure per year, $C_{R n}$ is radon concentration $\left(\mathrm{Bq} \mathrm{m}^{-3}\right), F$ is equilibrium factor ( 0.4 for indoor or workplaces and 0.6 for outdoor), 0.00027 is the concentration of radon progenies in equilibrium condition (WL Bq m${ }^{-3}$ ), $h$ is annual hours and $S$ is a fraction of working time for each worker that can be calculated by Eq. (6):

$S=W_{t} / 365.24$

where $W_{t}$ is working time in hours.

Equation (7) was used to estimate the annual effective dose contributed due to inhalation of radon [4]:

$H_{A}=W L M_{(Y)} \cdot I$

where $H_{A}$ is the effective dose ( $\mathrm{mSv}$ year $\left.{ }^{-1}\right)$ due to radon exposure, WLM year ${ }^{-1}$ is annual cumulative radon exposure and $I$ is the dose conversion factor as $10 \mathrm{mSv} \mathrm{WLM}^{-1}$ for workers [4]. Finally, the risk of lung cancer was estimated by Eq. (8) [1]:

$R=W L M_{(Y)} \cdot D \cdot K$

where $R$ is the lung cancer risk per year, $D$ is the exposure time (Year), and $K$ is the risk factor as $5 \times 10^{-4}$ per WLM based on ICRP publication 115 [18].

The calibrations were conducted using the same method explained in our previous publication [19-21].

\section{Results and discussion}

Table 1 shows the minimum detectable activity (MDA) and the average activity concentrations of ${ }^{40} \mathrm{~K},{ }^{226} \mathrm{Ra}$ and ${ }^{228} \mathrm{Ra}$ in the mine ore samples. The average activity concentration of ${ }^{40} \mathrm{~K}$ was measured higher than the worldwide average value (412 $\mathrm{Bq} \mathrm{kg}^{-1}$ ), while ${ }^{226} \mathrm{Ra}$ was just slightly above the worldwide average value $\left(32 \mathrm{~Bq} \mathrm{~kg}^{-1}\right)$, which is not significant considering the error interval [22].

According to Table 1, the highest amount of ${ }^{226} \mathrm{Ra}$ and ${ }^{40} \mathrm{~K}$ were found in site three as $39 \pm 5$ and $895 \pm 55 \mathrm{~Bq} \mathrm{~kg}^{-1}$ respectively, while site one has the highest concentration of ${ }^{228} \mathrm{Ra}$ as $43 \pm 6 \mathrm{~Bq} \mathrm{~kg}^{-1}$ in ore samples.

The outdoor gamma dose rate was measured between 69 and $93 \mathrm{nSv} \mathrm{h}^{-1}$ with an average of $84 \pm \mathrm{nSv} \mathrm{h}^{-1}$. The average indoor gamma exposure rate was also estimated at $116 \pm \mathrm{nSv}$ $\mathrm{h}^{-1}$.

Table 2 shows the measured radon concentration in different parts of the mine. Low levels of radon concentrations were measured in the mine area $\left(37 \pm 7\right.$ to $193 \pm 11 \mathrm{~Bq} \mathrm{~m}^{-3}$, with an average of $77 \pm 8 \mathrm{~Bq} \mathrm{~m}^{-3}$ ). Considering the results, the average radon concentration in all selected locations (except in three points) is less than $100 \mathrm{~Bq} \mathrm{~m}^{-3}$ and below the EPA, ICRP and EU-BSS recommendation level [1, 18, 23].

The daily average radon concentrations per location are shown in Fig. 3. The long-term radon concentration (30 days) was measured for site one, the largest site, as $118 \pm 12 \mathrm{~Bq} \mathrm{~m}^{-3}, 47 \pm 11 \mathrm{~Bq} \mathrm{~m}^{-3}$ for site two and $67 \pm 11 \mathrm{~Bq}$ $\mathrm{m}^{-3}$ for site three. The total average radon concentration in slate stone mine was also measured as $77 \pm 8 \mathrm{~Bq} \mathrm{~m}^{-3}$.

The surface radon exhalation was measured between $0.47 \pm 0.05$ and $0.53 \pm 0.05 \mathrm{mBq} \mathrm{m}^{-2} \mathrm{~s}^{-1}$, with an average of $0.5 \pm 0.05 \mathrm{mBq} \mathrm{m}^{-2} \mathrm{~s}^{-1}$, which is given in Table 3 and compared with findings of other studies.

The yearly effective dose due to the inhalation of radon is shown in Table 4 regarding each worker based on their working hours. The annual working time was calculated

Table 1 MDA and mass activity concentration of radionuclides in ore samples

\begin{tabular}{llll}
\hline Site & \multicolumn{3}{l}{ Activity concentration $\left(\mathrm{Bq} \mathrm{kg}^{-1}\right)$} \\
\cline { 2 - 4 } & ${ }^{226} \mathrm{Ra}$ & ${ }^{228} \mathrm{Ra}$ & ${ }^{40} \mathrm{~K}$ \\
\hline MDA & 1.3 & 2.3 & 46 \\
One & $38 \pm 5$ & $43 \pm 6$ & $825 \pm 47$ \\
Two & $36 \pm 4$ & $40 \pm 5$ & $887 \pm 53$ \\
Three & $39 \pm 5$ & $41 \pm 8$ & $895 \pm 55$ \\
Minimum & $36 \pm 4$ & $40 \pm 5$ & $825 \pm 47$ \\
Maximum & $39 \pm 5$ & $43 \pm 6$ & $895 \pm 55$ \\
Mean & $38 \pm 5$ & $41 \pm 6$ & $869 \pm 52$ \\
\hline
\end{tabular}


Table 2 Radon concentration in the mine's open area

\begin{tabular}{llrrrrrrrr}
\hline Location & \multicolumn{2}{l}{ Radon concentration $\left(\mathrm{Bq} \mathrm{m}^{-3}\right)$} \\
\cline { 2 - 9 } & Point 1 & SD & Point 2 & SD & Point 3 & SD & Point 4 & SD & Mean \\
\hline Site one & 83 & 12 & 193 & 11 & 104 & 10 & 94 & 16 & 118 \\
Site two & 38 & 12 & 49 & 9 & 46 & 13 & 53 & 12 & 47 \\
Site three & 37 & 7 & 39 & 9 & 58 & 10 & 132 & 19 & 67 \\
\hline
\end{tabular}

Fig. 3 Daily average of radon concentrations per site

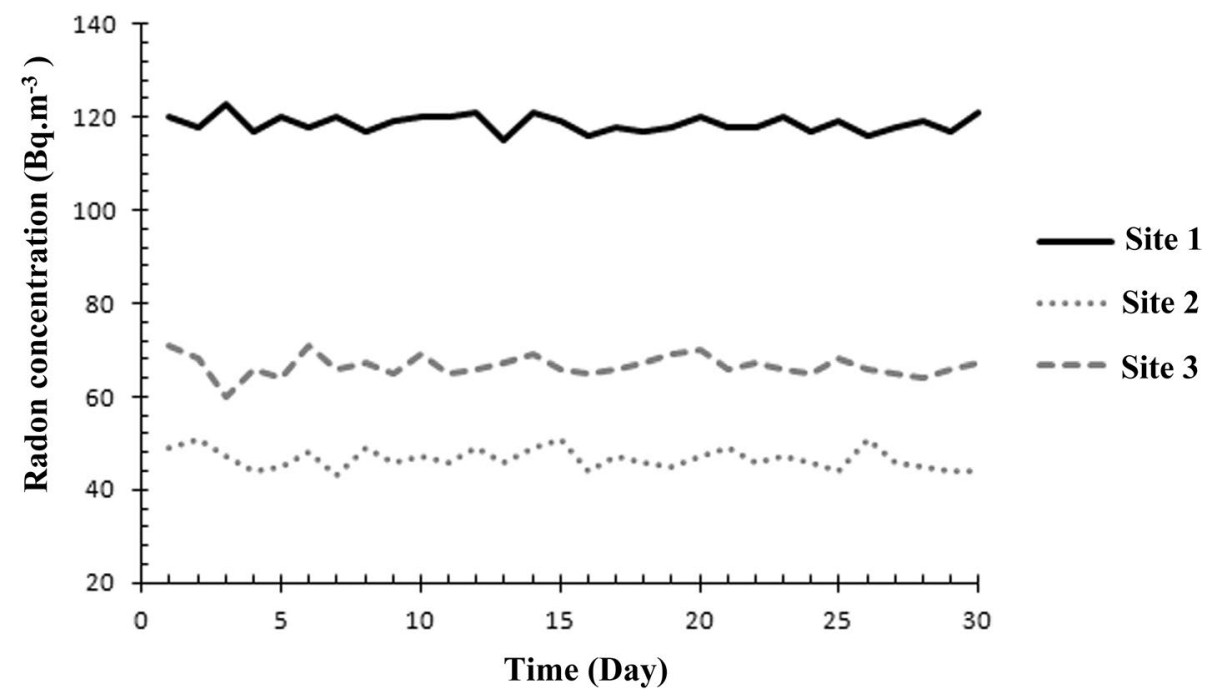

Table 3 Surface radon exhalation rate

\begin{tabular}{ll}
\hline Location & $\begin{array}{l}\text { Surface radon } \\
\text { exhalation }(\mathrm{mBq} \\
\left.\mathrm{m}^{-2} \mathrm{~s}^{-1}\right)\end{array}$ \\
\hline Site one & $0.50 \pm 0.05$ \\
Site two & $0.48 \pm 0.05$ \\
Site three & $0.47 \pm 0.05$ \\
Another study [24] & $0.49 \pm 0.05$ \\
\hline
\end{tabular}

approximately between 1600 and $2010 \mathrm{~h}$. The lowest radon exposure was recorded for transportation driver as $49 \pm 6 \mathrm{~Bq} \mathrm{~m}^{-3}$ and the highest one as $253 \pm 22 \mathrm{~Bq} \mathrm{~m}^{-3}$ for who works at the office. The office employees were among the most likely to be exposed to higher radon concentration (which might be due to the building materials and poor ventilation system) by an average of $211 \pm 20 \mathrm{~Bq} \mathrm{~m}^{-3}$. In contrast, the drivers were exposed to the lowest level of radon concentration $\left(51 \pm 6 \mathrm{~Bq} \mathrm{~m}^{-3}\right)$. It was assumed that the seasonal changes would not be significant (as it was confirmed by another study in the same type of mine in India [25]). Therefore, the yearly effective dose was assumed in fact of seasonal dose.
With annually 1600 working hours, the transport drivers were the lowest labour worker and the miners, with an average of 2010 working hours per year, were the most prolific workers. As a matter of fact, the lowest dose was obtained for drivers $\left(0.8 \pm 0.1 \mathrm{mSv}\right.$ year $\left.^{-1}\right)$ while the officers got the highest dose $\left(3.1 \pm 0.3 \mathrm{mSv}_{\text {year }}{ }^{-1}\right)$. The average total effective dose for all workers was calculated as $2.0 \pm 0.2 \mathrm{mSv}$ year $^{-1}$, which is below the recommended value considers by the national standard in case of exposure to radon and its decay products $\left(6 \mathrm{mSv}\right.$ year ${ }^{-1}$ or $\left.1000 \mathrm{~Bq} \mathrm{~m}^{-3}\right)$. According to the data obtained by this study, no miner exceeded the occupational maximum annual effective dose limit $(5 \mathrm{mSv}$ year $\left.^{-1}\right)$. The excess yearly lung cancer risk was calculated between $0.3 \times 10^{-2}$ and $1.3 \times 10^{-2}$ with an average of $0.8 \times$ $10^{-2}$ per 100 individuals based on the total annual effective dose. Table 4 presents the lung cancer risks due to exposure to radon and its progenies for each worker.

Figures 4 and 5 show the correlation between the annual effective dose and the risk of lung cancer considering the working hours in terms of profession. It is revealed that there is a strong positive correlation between working hours and receiving dose $\left(\mathrm{R}^{2}=0.817\right)$.

The employees who work at offices were exposed to the highest radon concentration level but still below the recommended level. In contrast, miners were exposed to the lowest radon level among all other workers (except drivers who spend most of their time out of the mine's environment). 
Table $4{ }^{222} \mathrm{Rn}$ concentration and occupational dose in related to working place

\begin{tabular}{|c|c|c|c|c|c|c|}
\hline \multirow[t]{2}{*}{ Worker } & \multirow[t]{2}{*}{ Working hours } & \multirow{2}{*}{$\begin{array}{l}{ }^{222} \mathrm{Rn} \text { concentra- } \\
\text { tion }\left(\mathrm{Bq} \mathrm{m}^{-3}\right)\end{array}$} & \multicolumn{2}{|c|}{ Annual effective dose $\left(\mathrm{mSv}\right.$ year $\left.{ }^{-1}\right)$} & \multirow{2}{*}{$\begin{array}{l}\text { Annual effective } \\
\text { dose }\left(\mathrm{mSv} \text { year }^{-1}\right)\end{array}$} & \multirow{2}{*}{$\begin{array}{l}\text { Annual risk } \\
\text { of lung cancer } \\
\left(\times 10^{-5}\right)\end{array}$} \\
\hline & & & Exposure to radon & $\begin{array}{l}\text { Exposure to } \\
\text { gamma radiation }\end{array}$ & & \\
\hline Miner & 2010 & $80 \pm 8$ & $1.5 \pm 0.2$ & 0.18 & $1.7 \pm 0.2$ & $6.38 \pm 0.78$ \\
\hline Miner & 2010 & $72 \pm 7$ & $1.4 \pm 0.2$ & 0.18 & $1.6 \pm 0.2$ & $5.75 \pm 0.67$ \\
\hline Miner & 2010 & $113 \pm 11$ & $2.26 \pm 0.2$ & 0.19 & $2.5 \pm 0.5$ & $9.01 \pm 1.05$ \\
\hline Miner & 2010 & $95 \pm 10$ & $1.8 \pm 0.2$ & 0.19 & $2.0 \pm 0.3$ & $7.58 \pm 0.97$ \\
\hline Miner & 2010 & $77 \pm 8$ & $1.5 \pm 0.2$ & 0.14 & $1.1 \pm 0.2$ & $6.15 \pm 0.77$ \\
\hline Miner & 2010 & $56 \pm 6$ & $1.0 \pm 0.1$ & 0.14 & $1.2 \pm 0.1$ & $4.47 \pm 0.59$ \\
\hline Officer & 1960 & $253 \pm 22$ & $3.1 \pm 0.3$ & 0.23 & $3.4 \pm 0.3$ & $13.12 \pm 1.40$ \\
\hline Officer & 1960 & $179 \pm 17$ & $2.2 \pm 0.3$ & 0.23 & $2.4 \pm 0.3$ & $9.29 \pm 1.07$ \\
\hline Officer & 1960 & $173 \pm 16$ & $2.1 \pm 0.2$ & 0.23 & $2.4 \pm 0.2$ & $8.97 \pm 1.0$ \\
\hline Officer & 1960 & $247 \pm 22$ & $3.1 \pm 0.3$ & 0.23 & $3.3 \pm 0.3$ & $12.81 \pm 1.41$ \\
\hline Officer & 1960 & $202 \pm 21$ & $2.5 \pm 0.3$ & 0.23 & $2.7 \pm 0.3$ & $10.48 \pm 1.29$ \\
\hline Engineer & 1820 & $154 \pm 15$ & $1.8 \pm 0.2$ & 0.21 & $2 . \pm 0.2$ & $7.42 \pm 0.89$ \\
\hline Engineer & 1670 & $162 \pm 16$ & $1.7 \pm 0.2$ & 0.19 & $1.9 \pm 0.2$ & $7.16 \pm 0.88$ \\
\hline Driver & 1600 & $52 \pm 6$ & $0.8 \pm 0.1$ & 0.14 & $0.9 \pm 0.1$ & $3.30 \pm 0.47$ \\
\hline Driver & 2010 & $49 \pm 6$ & $0.9 \pm 0.1$ & 0.19 & $1.1 \pm 0.1$ & $3.91 \pm 0.58$ \\
\hline Average & & $131 \pm 13$ & $1.8 \pm 0.2$ & 0.17 & $2.0 \pm 0.2$ & $7.72 \pm 0.92$ \\
\hline Min & & $49 \pm 6$ & $0.8 \pm 0.1$ & 0.11 & $0.9 \pm 0.1$ & $3.30 \pm 0.47$ \\
\hline $\operatorname{Max}$ & & $253 \pm 22$ & $3.1 \pm 0.3$ & 0.23 & $3.3 \pm 0.3$ & $13.12 \pm 1.40$ \\
\hline
\end{tabular}

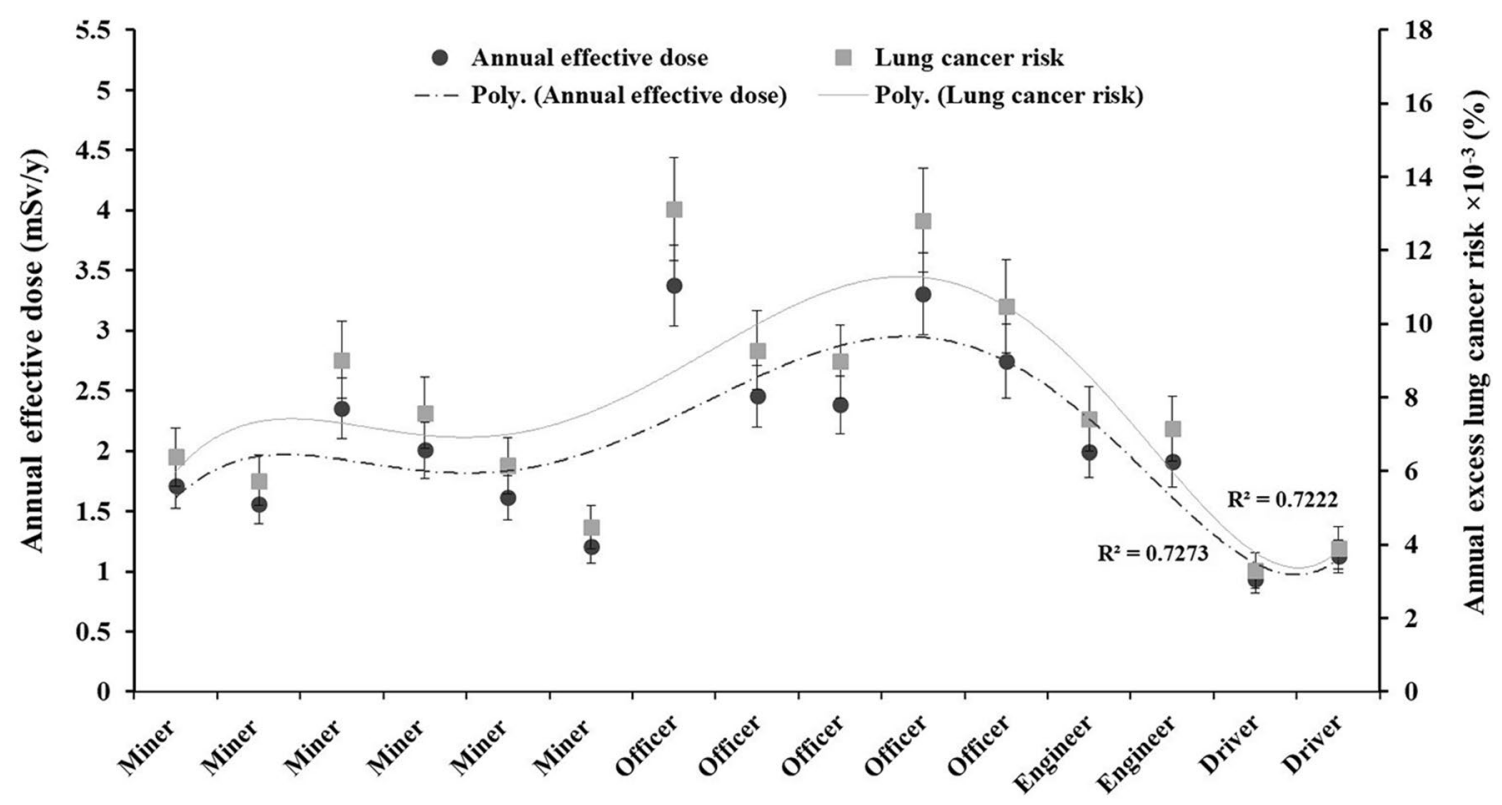

Job Position

Fig. 4 The correlation between the annual effective doses and annual excess lung cancer risk with the job position

The findings of this study are similar to the other research in India, and the slight difference in estimated dose might be due to the measurement method. In the current research, personal radon dosimetry was used, while in another study, the average radon concentration at the mine environment had been considered for dose estimation. Table 5 shows a comparison between this study's findings and the data from other studies to overview the obtained results. 
Fig. 5 The correlation between the effective doses and working hours with the job position

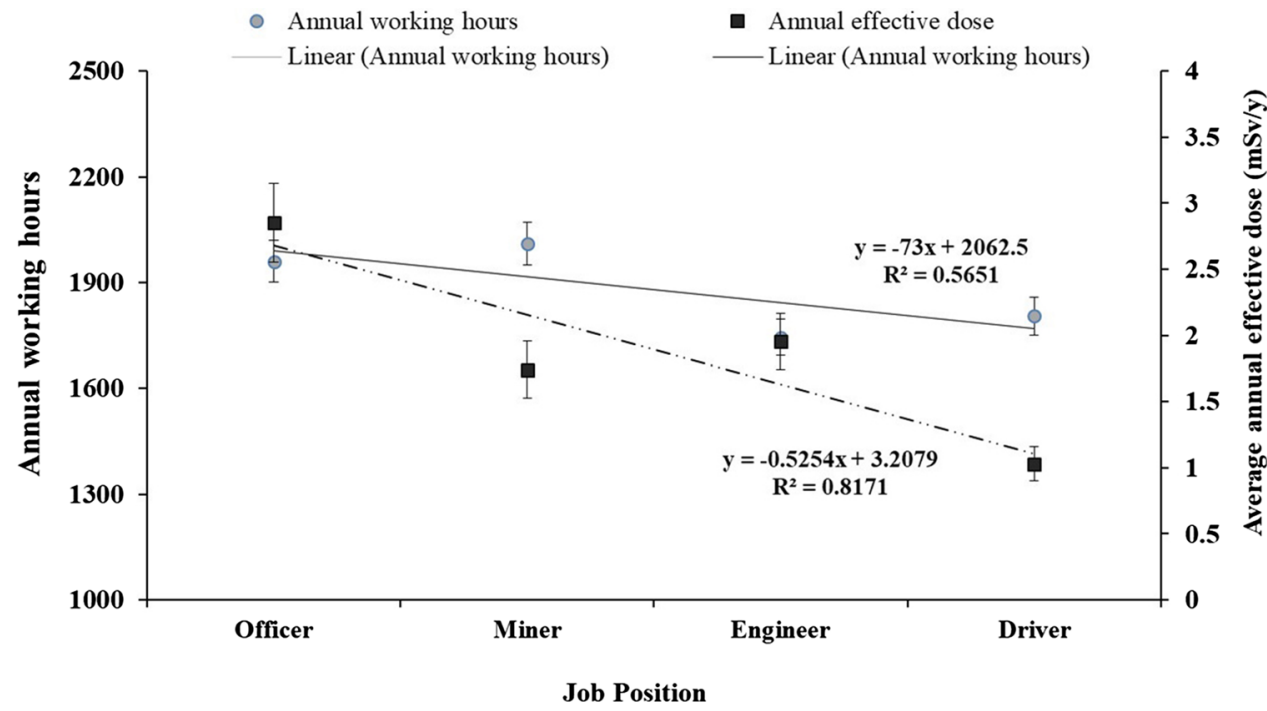

Table 5 Results comparison

\begin{tabular}{llll}
\hline Mine location & $\begin{array}{l}{ }^{222} \mathrm{Rn} \text { concen- } \\
\text { tration }(\mathrm{Bq} \\
\left.\mathrm{m}^{-3}\right) \text { Min.-Max. } \\
(\text { Av. })\end{array}$ & $\begin{array}{l}\text { Effective } \\
\text { dose }(\mathrm{mSv} \\
\left.\text { year }^{-1}\right) \mathrm{Av} .\end{array}$ & Reference \\
\hline Kashan & $37-193(77)$ & 1.8 & Current study \\
Mahu & $24-95(47)$ & 0.8 & {$[25]$} \\
Nahrika & $21-101(43)$ & 0.7 & \\
Chitora & $22-113(52)$ & 0.9 & \\
Chimravat & $33-88(38)$ & 0.7 & \\
Kheri Kalan & $33-103(42)$ & 0.7 & \\
\hline
\end{tabular}

\section{Conclusions}

The average activity concentration of ${ }^{226} \mathrm{Ra},{ }^{228} \mathrm{Ra}$ and ${ }^{40} \mathrm{~K}$ was measured as $38 \pm 5,41 \pm 6$ and $869 \pm 52 \mathrm{~Bq} \mathrm{~kg}^{-1}$, respectively. The surface radon exhalation was measured between $0.47 \pm 0.05$ and $0.53 \pm 0.05 \mathrm{mBq} \mathrm{m}^{-2} \mathrm{~s}^{-1}$, with an average of $0.50 \pm 0.05 \mathrm{mBq} \mathrm{m}^{-2} \mathrm{~s}^{-1}$. Low levels of ${ }^{222} \mathrm{Rn}$ concentration were measured at the mine area (from $37 \pm 7$ to $193 \pm 11 \mathrm{~Bq} \mathrm{~m}^{-3}$ with an average of $77 \pm 8 \mathrm{~Bq}$ $\mathrm{m}^{-3}$ ). The drivers were exposed to the lowest radon concentration $\left(49 \pm 6 \mathrm{~Bq} \mathrm{~m}^{-3}\right)$, while the employees who worked at the offices were exposed to the highest radon concentration $\left(253 \pm 22 \mathrm{~Bq} \mathrm{~m}^{-3}\right)$. Therefore, the total average annual effective dose was estimated, based on workplace, and working time, in the range of $0.94 \pm 0.11 \mathrm{mSv}$ year $^{-1}$ (drivers) to $3.38 \pm 0.33 \mathrm{mSv}_{\text {year }}{ }^{-1}$ (officers), with a mean value of $2.04 \pm 0.22 \mathrm{mSv}_{\text {year }}{ }^{-1}$ which is lower than ICRP and national recommended value $\left(5 \mathrm{mSv}\right.$ year $\left.{ }^{-1}\right)$. The annual lung cancer risk was calculated with an average of $7.72 \times 10^{-2} \%$. Further study is recommended to measure the actual equilibrium factor in the mine area and its influence on the dose and investigate the other exposure pathways, such as dust inhalation.

Funding Open access funding provided by University of Pannonia. The present study was supported by Kutatási, Fejlesztési és Innovaciós Alap (NKFI-1) (Hungarian National Scientific Research Funding Programs) Grants Nos. K128818OTKA, 128818 and K128805.

Availability of data and materials Presented in the paper.

\section{Declarations}

Ethics approval and consent to participate Not applicable.

Conflict of interest The author/s stated any conflicts of interest corresponding to the research, authorship or/and publication of this article.

Open Access This article is licensed under a Creative Commons Attribution 4.0 International License, which permits use, sharing, adaptation, distribution and reproduction in any medium or format, as long as you give appropriate credit to the original author(s) and the source, provide a link to the Creative Commons licence, and indicate if changes were made. The images or other third party material in this article are included in the article's Creative Commons licence, unless indicated otherwise in a credit line to the material. If material is not included in the article's Creative Commons licence and your intended use is not permitted by statutory regulation or exceeds the permitted use, you will need to obtain permission directly from the copyright holder. To view a copy of this licence, visit http://creativecommons.org/licenses/by/4.0/.

\section{References}

1. Environmental Protection Agency (2003) EPA assessment of risks from radon in homes. Office of Radiation and Indoor Air, Washington DC

2. World Health Organization (2009) WHO handbook on indoor radon. WHO, Geneva 
3. International Atomic Energy Agency (2014) Radiation protection and safety of radiation sources: international basic safety standards IAEA safety standards general safety requirements part 3 no. GSR part 3. WHO, Vienna

4. ICRP (2017) Occupational Intakes of Radionuclides: Part 3. ICRP Publication 137. Ann ICRP. 46

5. The United Nations Scientific Committee on the Effects of Atomic Radiation (2000) UNSCEAR 2000 report: sources and effects of ionizing radiation, vol I. United Nations, New York

6. Shahrokhi A, Burghele BD, Fábián F, Kovács T (2015) New study on the correlation between carbon dioxide concentration in the environment and radon monitor devices. J Environ Radioact 150:57-61

7. Orabi M (2017) Radon release and its simulated effect on radiation doses. Health Phys. https://doi.org/10.1097/hp.0000000000 000630

8. Shahrokhi A, Kovács T (2021) Radiological survey on radon entry path in an underground mine and implementation of an optimized mitigation system. Environ Sci Eur (Accepted)

9. Kardos R, Sas Z, Hegedûs M, Shahrokhi A, Somlai J, Kovacs T (2015) Radionuclide content of NORM by-products originating from the coal-fired power plant in Oroszlány (Hungary). Radiat Prot Dosimetry 167:266-269

10. Shahrokhi A, Adelikhah M, Chalupnik S, Kocsis E, Toth-Bodrogi E, Kovács T (2020) Radioactivity of building materials in Mahallat, Iran-an area exposed to a high level of natural background radiation-attenuation of external radiation doses. Materiales de Construcción 70:e233

11. Shahrokhi A, Adelikhah M, Chalupnik S, Kovács T (2021) Multivariate statistical approach on distribution of natural and anthropogenic radionuclides and associated radiation indices along the north-western coastline of Aegean Sea, Greece. Mar Pollut Bull. https://doi.org/10.1016/j.marpolbul.2021.112009

12. Bé MM, Chechev VP, Dersch R, Helene OAM, Helmer RG, Herman $M$ et al (2007) Update of $x$ ray and gamma ray Decay data standards for detector calibration and other applications. International Atomic Energy Agency, Vienna

13. Amin Shahrokhi T, Vigh C, Németd A, Csordás T, Kovács (2017) Radon measurements and dose estimate of workers in a manganese ore mine. Appl Radiat Isot. https://doi.org/10.1016/j.aprad iso.2017.02.047

14. Shahrokhi A, Nagy E, Csordás A, Somlai J, Kovács T (2016) Distribution of indoor radon concentrations between selected Hungarian thermal baths. Nukleonika 61:333-336. https://doi. org/10.1515/nuka-2016-0055

15. Shahrokhi A, Shokraee F, Reza A, Rahimi H (2015) Health risk assessment of household exposure to indoor radon in association with the dwelling's age. J Radiat Prot Res 40:155. https://doi.org/ 10.14407/jrp.2015.40.3.155
16. Múllerová M, Mazur J, Blahušiak P, Grządziel D, Holý K, Kovács T et al (2016) Preliminary results of radon survey in thermal spas in V4 countries. Nukleonika 61:303-306

17. Adelikhah M, Shahrokhi A, Chalupnik S, Tóth-Bodrogi E, Kovács $\mathrm{T}$ (2020) High level of natural ionizing radiation at a thermal bath in Dehloran. Iran Heliyon. https://doi.org/10.1016/j.heliyon.2020. e04297

18. Tirmarche M, Harrison JD, Laurier D, Paquet F, Blanchardon E, Marsh JW (2010) ICRP Publication 115. Lung cancer risk from radon and progeny and statement on radon. Ann ICRP 40:1-64

19. Kovács T, Shahrokhi A, Sas Z, Vigh T, Somlai J (2017) Radon exhalation study of manganese clay residue and usability in brick production. J Environ Radioact. https://doi.org/10.1016/j.jenvrad. 2016.07.014

20. Adelikhah M, Shahrokhi A, Imani M, Chalupnik S, Kovács T (2021) Radiological assessment of indoor Radon and Thoron concentrations and indoor Radon map of dwellings in Mashhad. Iran. Int J Environ Res Public Health 18:141. https://doi.org/10.3390/ ijerph18010141

21. Múllerová M, Mazur J, Blahušiak P, Grządziel D, Holý K, Kovács $\mathrm{T}$, Kozak K, et al (2016) Indoor radon activity concentration in thermal spas: the comparison of three types of passive radon detectors. J Radioanal Nucl Chem. https://doi.org/10.1007/ s10967-016-4961-8

22. United Nations Scientific Committee on the Effects of Atomic Radiation (2008) Sources and Effects of Ionizing Radiation, United Nations Scientific Committee on the Effects of Atomic Radiation (UNSCEAR) 2008 Report, Volume I. United Nations, New York. https://doi.org/10.18356/cb7b6e26-en

23. Council of the European Union (2014) Council Directive 2013/59/ Euratom of 5 December 2013 laying down basic safety standards for protection against the dangers arising from exposure to ionising radiation, and repealing Directives 89/618/Euratom, 90/641/ Euratom, 96/29/Euratom, 97/43/Euratom and 2003/122/Euratom. Off J Eur Union L13:1970-0677

24. Chen J, Rahman NM, Atiya IA (2010) Radon exhalation from building materials for decorative use. J Environ Radioact. https:// doi.org/10.1016/j.jenvrad.2010.01.005

25. Kant K, Kuriakose S, Sharma GS (2009) Radon activity and the radiation dose levels in the slate mines in aravali range in India. $\mathrm{J}$ Geol Min Res 1:156-158

Publisher's Note Springer Nature remains neutral with regard to jurisdictional claims in published maps and institutional affiliations. 